\title{
Uptake and Intracellular Localization of Exogenous L-DOPA, L-Leucine and their Metabolites in the Gastro-Enteric Endocrine Cells of the Mouse Studied by Electron Microscope Autoradiography*
}

\author{
Shigeru KoBayashi
}

Received October 30, 1974

Summary: L-DOPA- ${ }^{3} \mathrm{H}(50 \mu \mathrm{Ci} / \mathrm{g}$. b.w. $)$ was injected intraperitoneally in two mice. They were killed $1 \mathrm{hr}$ and $24 \mathrm{hrs}$ after the injection and pieces of the gut were processed for both light and electron microscope autoradiography after fixation in glutaraldehyde followed by post-fixation with osmium tetroxide. At $1 \mathrm{hr}$, a greater number of specific silver grains were found on EC cells than on other types of basal-granulated cells including $G, L$ (EG) and ECL cells. At $24 \mathrm{hrs}$, a considerable number of labels were found on only a few EC cells. Subcellular localization of $L-D O P A-{ }^{3} \mathrm{H}$ and its metabolites was studied by electron microscope autoradiography. By $1 \mathrm{hr}$ after the injection, specific radioactivity accumulated in the cytoplasm rich in secretory granules. Labeling on the Golgi area was conspicuously lower than in the granule-rich cytoplasm.

To study the process of the synthesis of secretory proteins, L-leucine- ${ }^{3} \mathrm{H}(100 \mu \mathrm{Ci} / \mathrm{g} . \mathrm{b} . w$. was injected into the peritoneal cavity of two mice which were killed at $30 \mathrm{mins}$ and $2.5 \mathrm{hrs}$ after the injection. It was apparent that all morphologic types of basal-granulated cells had an ability to uptake exogenous leucine to synthesize proteins/polypeptides. At 30 mins, specific silver grains were found primarily on the Golgi area. By $2.5 \mathrm{hrs}$, however, silver grains were mainly associated with the secretory granules and frequently conglomerated to form a cluster of them in the cytoplasmic area rich in secretory granules.

These results are consistent with the view that in all types of basal-granulated cells the secretory granules together with their protein contents are formed in the Golgi area, and then incorporate amines from the cytosol to become ready to be released by exocytosis.

During the past ten years it has been established that gastro-enteric hormones such as secretin, gastrin and CCK-PZ are secreted from a group of cells called basalgranulated cells (see the reviews by Fujita and Kobayashi, 1973; Pearse, 1974; PoLAK, 1974). These cells are dispersed within other epithelial cells of the gastroenteric mucosa and share many histochemical and ultrastructural characteristics with the accepted endocrine cells which secrete proteins and/or polypeptides together with some biogenic monoamines. Based on the ultrastructure of their secretory granules, basal-granulated cells can be classified into several types, probably corresponding to different gastro-enteric hormones (CAPElla, Solcia and VASSallo, 1969; Forssmann et al., 1969; Kobayashi, Fujita and Sasagawa, 1970; Pearse et al., 1970; see also Fujita and Kobayashi, 1973 and Pearse 1974).

\footnotetext{
* The major part of this work was carried out in the Department of Human Morphology, Nottingham University, Britain, where the author was a research fellow. Sincere thanks are due to Professor R. E. Coupland for providing the opportunity to study the autoradiographic technique. Thanks are also due to the Wellcome Trust for financial support.
} 
In several protein/polypeptide secreting endocrine glands, it is possible to get a fairly pure fraction of the subcellular component such as secretory granules for biochemical analysis. Although the fine structure of the basal-granulated cells of the gut is reminiscent of that of the protein/polypeptide secreting endocrine cells elsewhere, it seems to be difficult to collect the fraction of subcellular components of the basal-granulated cells with a degree of purity sufficient for the biochemical analysis, since the basal-granulated cells are dispersed among other epithelial cells that often contain granules of various size and shape. Therefore, an understanding of the chemical composition of the secretory granules and of the mechanism of their formation and release is yet incomplete in the basal-granulated cells.

One of the advantages of the electron microscope autoradiography over the combined cell fractionation and biochemical method might be that, by autoradiography, it is possible to see the intracellular localization of radioisotope-labeled substances in a single cell without homogenizing tissues. Thus, it is not an essential handicap in the study of the secretory process at the subcellular level that the basal-granulated cells are dispersed among other epithelial cells. Another advantage of the electron microscope autoradiography might be that one may be able to demonstrate the difference, if present, in the activity of individual cell types, which may be identified by their ultrastructural characteristics.

\section{Materials and Methods}

Four young male mice of CS 1 strain were used. Table 1 shows their details. L-DOPA- ${ }^{3} \mathrm{H}$ ( L-3(3, 4-dihydroxyphenyl) alanine (ring-2, 5, 6-3 H); sp. act. $31.8 \mathrm{Ci}$ $/ \mathrm{mmol}$ ) and L-leucine-4, 5-3 $\mathrm{H}$ (sp. act. $48.0 \mathrm{Ci} / \mathrm{mmol}$ ) were obtained from the Radiochemical Center, Amersham, England, as a $2 \%$ ethanol solution. They were dried at room temperature under nitrogen gas to be solved again in a small amount of distilled water in order to get a concentration of radioactivity adequate for the injection (less than $0.01 \mathrm{ml} / \mathrm{g}$. b.w.).

At certain time points after an intraperitoneal injection of either L-DOPA-3 $\mathrm{H}$ or $\mathrm{L}$-leucine- ${ }^{3} \mathrm{H}$, the mice were killed by cervical dislocation, and the thorax and abdomen were widely opened. About $20 \mathrm{ml}$ of $2.5 \%$ glutaraldehyde in $0.1 \mathrm{M}$ phosphate buffer of $\mathrm{pH} 7.2$ was perfused through an injection needle that was inserted into the left ventricle of the heart. Then, a small amount of the same fixative was injected from the inferior vena cava to reassure the perfusion fixation. Pieces of the glandular stomach and duodenum were removed and further fixed in the fixative at room

Table 1. Plan of experiment

\begin{tabular}{cccccc}
\hline Mouse & $\begin{array}{c}\text { Age when } \\
\text { injected } \\
(\text { days })\end{array}$ & $\begin{array}{c}\text { Weight when } \\
\text { injected } \\
(\mathrm{g})\end{array}$ & $\begin{array}{c}\text { Tritiated substance } \\
\text { injected }\end{array}$ & $\begin{array}{c}\text { Dose } \\
(\mu \mathrm{Ci} \text { /g.b.w })\end{array}$ & $\begin{array}{c}\text { Time after } \\
\text { labeling } \\
(\mathrm{hrs})\end{array}$ \\
\hline 1 & 35 & 20.9 & L-DOPA & 50 & 1 \\
2 & 35 & 20.6 & L-DOPA & 50 & 24 \\
3 & 26 & 11.8 & L-leucine & 100 & 0.5 \\
4 & 26 & 13.2 & L-leucine & 100 & 2.5 \\
\hline
\end{tabular}


temperature overnight. Then, they were post-fixed in $1.0 \%$ osmium tetroxide at room temperature for $2 \mathrm{hrs}$. After dehydration in graded concentrations of ethanol the tissue was embedded in Araldite.

For light microscope autoradiography sections $1.0 \mu \mathrm{m}$ thick were cut on a Cambridge-Huxley microtome and mounted on glass slides coated with a mixture of gelatin and chrome-alum. Ilford G5 emulsion (Ilford Ltd., Ilford, Essex, England) was applied to the section by the dipping method to produce an emulsion layer about $3 \mu \mathrm{m}$ thick. Autoradiograms were exposed in a light-tight box containing Silica gel at $4^{\circ} \mathrm{C}$ for periods of 3 to 54 days and thereafter developed in Kodak D-19 developer for 4 mins at $20^{\circ} \mathrm{C}$, briefly rinsed in $1.0 \%$ acetic acid, fixed in Ilford Hypam rapid fixer, stained with newly-prepared toluidine blue in a phosphate buffer of $\mathrm{pH} 7.4$ for 6 mins at $55-60^{\circ} \mathrm{C}$ and then examined and photographed in the light microscope.

For electron microscope autoradiography ultra-thin sections of silver or gold interference colour were cut on a Cambridge-Huxley microtome. Ribbons of sections were transferred to collodion-coated glass slides by means of a thin sable brush. After removing water on a hot plate, sections were stained with $1.0 \%$ aqueous solution of uranyl acetate for 4 mins, then with MiLLONIG's lead solution for 10 mins. They were then coated with a thin layer of carbon. Monolayer of Ilford L4 emulsion was applied by the dipping method. The autoradiograms were exposed at $4^{\circ} \mathrm{C}$ for $4-15$ weeks in a light-tight box with Silica gel, developed in Kodak D-19 developer at $20^{\circ} \mathrm{C}$ for $2.5-$ 3.0 mins, and fixed in $30 \%$ sodium thiosulfate. According to the data published by SALPETER and McHenry (1973), the resolution designated as the half-distance value (HD) for this autoradiographic system (Ilford L4, purple interference, 100-120 $\mathrm{m}$ thick section, D-19 developer, etc.) is $145 \mathrm{~nm}$.

\section{Results}

\section{Fine structure of basal-granulated cells}

In the glandular stomach and duodenum of the mouse several types of basalgranulated cells were encountered in the present material. They were tentatively identified as the equivalent of the EC, G, L(EG) and ECL cells in man and other mammalian species in which the ultrastructure of the basal-granulated cells has been described (for reference see Sasagawa, Kobayashi and Fujita, 1973). However, it was sometimes difficult or impossible to classify individual basal-granulated cells only by ultrastructural criteria.

EC cells were characterized by the irregularly shaped granules of very high electron density. In the glandular stomach they had a smaller number of secretory granules per area of the cytoplasm as compared with those in the duodenum. Many secretory granules in the EC cells of the stomach were round or oval in shape and had a wide, clear halo between the limiting membrane and the core. L(EG) cells were characterized by round, relatively large secretory granules of medium electron density. They corresponded to type 2 or intestinal A cells of Forssmann et al. (1969) and RuBin et al. (1971). G cells were characterized by mixed vacuolized and solid granules. Occurrence of ECL cells seemed to be confined to the oxyntic cell area of the glandular stomach and their secretory granules were a mixture of large vacuolated ones with a gray core and small, round ones with fine-granular content. They 
corresponded to the cell type which was described by Rubin et al. (1971) as the cells resembling type 4 or entero-catecholamine cells of Forssmann et al. (1969).

In cll types of the basal granulated cells the granules in the Golgi area had different morphological features as compared with those in the basal and paranuclear cytoplasm. Firstly, granules in the Golgi area were variable in size, but usually smaller than those in other parts of the cytoplasm. Secondly, the contents of the granules in the Golgi area were variable, mostly less dense, but sometimes denser and showed fine granularity in the high power electron micrograph. Thirdly, granules in the Golgi region were frequently associated with one or more coated pits. Thus, in the EC cells, as shown in Figures 6 and 14, granules in the Golgi area were usually small, rounded in shape and the halo between the limiting membrane and the core was clear. In the $\mathrm{G}$ cells, small round granules in the Golgi area had a continuous limiting membrane, while granules with a pale content in the basal cytoplasm had a disrupted limiting membrane (Fig. 16). There was every transitional form between small round granules of relatively high electron density and larger pale granules with a disrupted limiting membrane either in the apical or in the basal cytoplasm of G cells. In the ECL cells, large, vacuolated types of granules were rare in the Golgi area (Fig. 17).

\section{Localization of L-DOPA and its metabolites}

In the specimen of the gastric mucosa taken $1 \mathrm{hr}$ after an intraperitoneal injection of L-DOPA- ${ }^{3} \mathrm{H}$, specific radioactivity was observed on the basal-granulated cells and mast cells with little background activity (Fig. 1). Silver grains which indicate
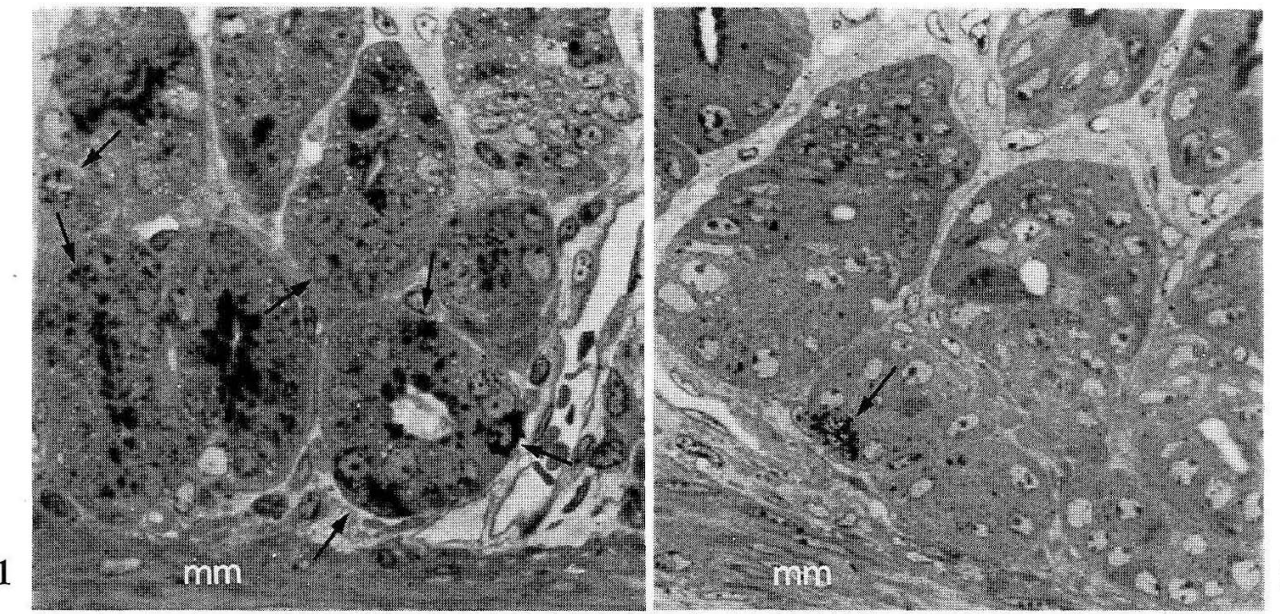

Fig. 1-5. Light microscope autoradiograms of the mouse stomach and duodenum after an intraperitoneal injection of L-DOPA- ${ }^{3} \mathrm{H}$.

Fig. 1. Pyloric gland area of the stomach $1 \mathrm{hr}$ after the injection of $\mathrm{L}-\mathrm{DOPA}-{ }^{3} \mathrm{H}$. Deeper portion of the pyloric glands is shown in this micrograph. The cytoplasm of several basal-granulated cells is heavily labeled (arrows). $m m$ Lamina muscularis mucosae. 54 day exposure. $\times 450$

Fig. 2. Pyloric gland area of the stomach 24 hrs after the injection of L-DOPA- ${ }^{3} \mathrm{H}$. Labeled cells (arrow) are strikingly small in number as compared with those in the specimen taken $1 \mathrm{hr}$ after the injection shown in Figure 1. $\quad \mathrm{mm}$ Lamina muscularis mucosae. 54 day exposure. $\quad \times 450$ 
the presence of exogenous L-DOPA- ${ }^{3} \mathrm{H}$ and its metabolites were seen both on the nucleus and the cytoplasm of the basal-granulated cells. However, the numbers of the silver grains per cell varied from cell to cell. The heaviest labeling was seen on those basal-granulated cells which were thought to be EC cell in type, because their basal granules stained intensely with toluidine blue. On a few basal-granulated cells no silver grains were found. These cells were usually pale in toluidine blue-stained autoradiograms but the identification of exact cell type was unknown. In the specimen taken 24 hrs after the injection, labeled basal-granulated cells strikingly decreased
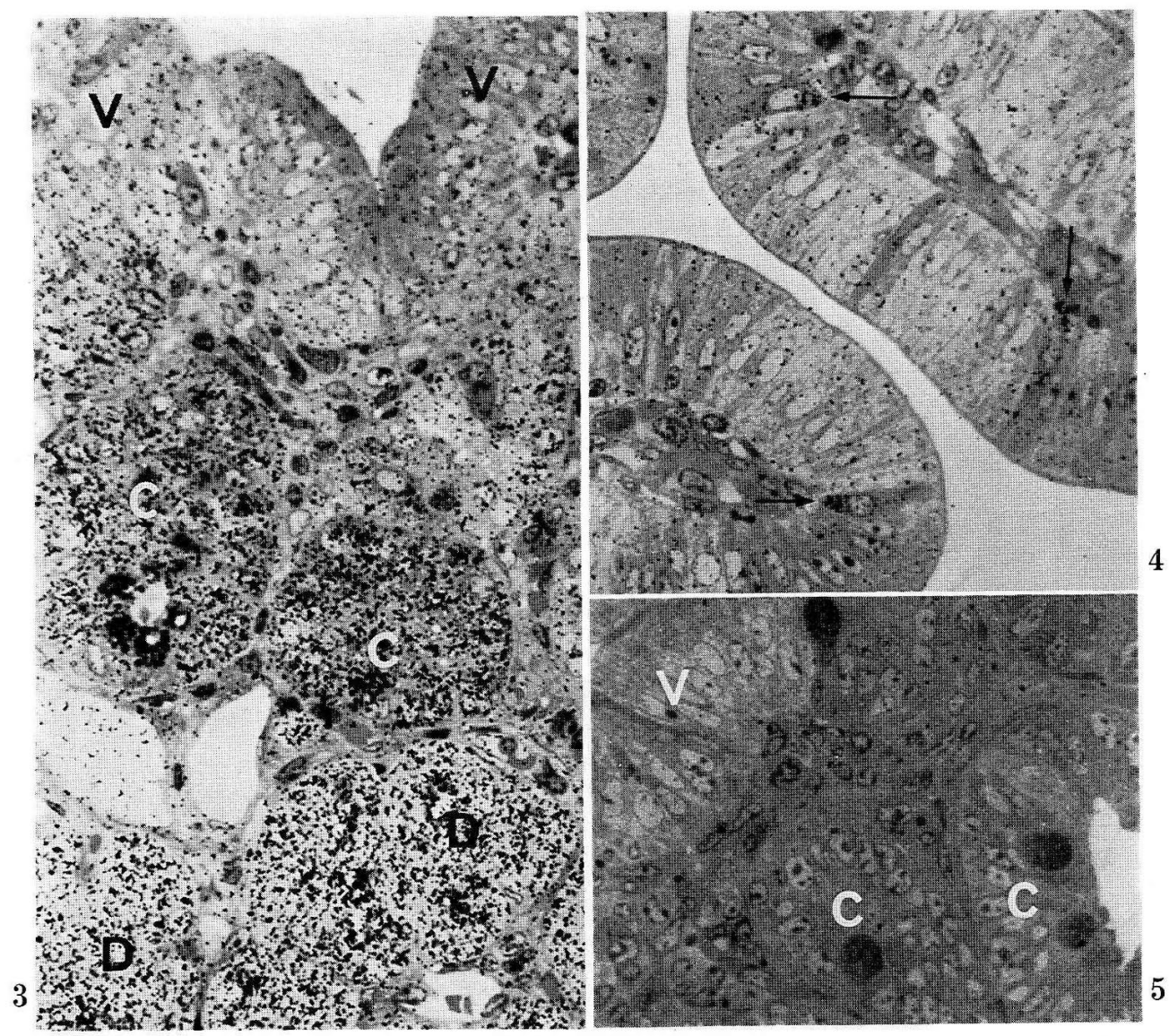

Fig. 3. Duodenum $1 \mathrm{hr}$ after the injection of L-DOPA- ${ }^{3} \mathrm{H}$. Many silver grains are seen on the duodenal gland cells $(D)$ and both crypt- $(C)$ and villus-epithelium $(V)$. The crypt-epithelium is labeled obviously heavier than the villus-epithelium and duodenal gland cells. It is difficult to identify basal-granulated cells in this specimen. 54 day exposure. $\quad \times 450$

Fig. 4. Duodenal villi $1 \mathrm{hr}$ after the injection of $\mathrm{L}-\mathrm{DOPA}-{ }^{3} \mathrm{H}$. There are three basal-granulated cells (probably EC cells) whose basal cytoplasm is heavily labeled (arrows). A considerable number of specific silver grains are seen on the enterocytes covering the villi. 54 day exposure. $\times 450$

Fig. 5. Duodenum 24 hrs after the injection of L-DOPA $-{ }^{3} \mathrm{H}$. Practically no silver grains are seen on any structure in this specimen. It is apparent that L-DOPA incorporated into various kinds of cells of the duodenum by $1 \mathrm{hr}$ after the injection comes out of the cells within $24 \mathrm{hrs}$. C cryptepithelium, $V$ villus-epithelium. 54 day exposure. $\times 450$ 
in number (Fig. 2). Occasionally, heavily-labeled cells were found, especially in the deeper portion of the gastric gland. These cells were apparently EC in type, but some of the EC cells were devoid of specific silver grains.

In the specimen of the duodenum taken $1 \mathrm{hr}$ after the administration of L-DOPA${ }^{3} \mathrm{H}$, many silver grains were seen on the cells of the duodenal gland and on the epithelial cells in the crypt (Fig. 3). A few silver grains were found on the enterocytes and goblet cells (Fig. 4) on the villi and on the Paneth and goblet cells in the crypts. Most of the basal-granulated cells identified were labeled, but the number of specific

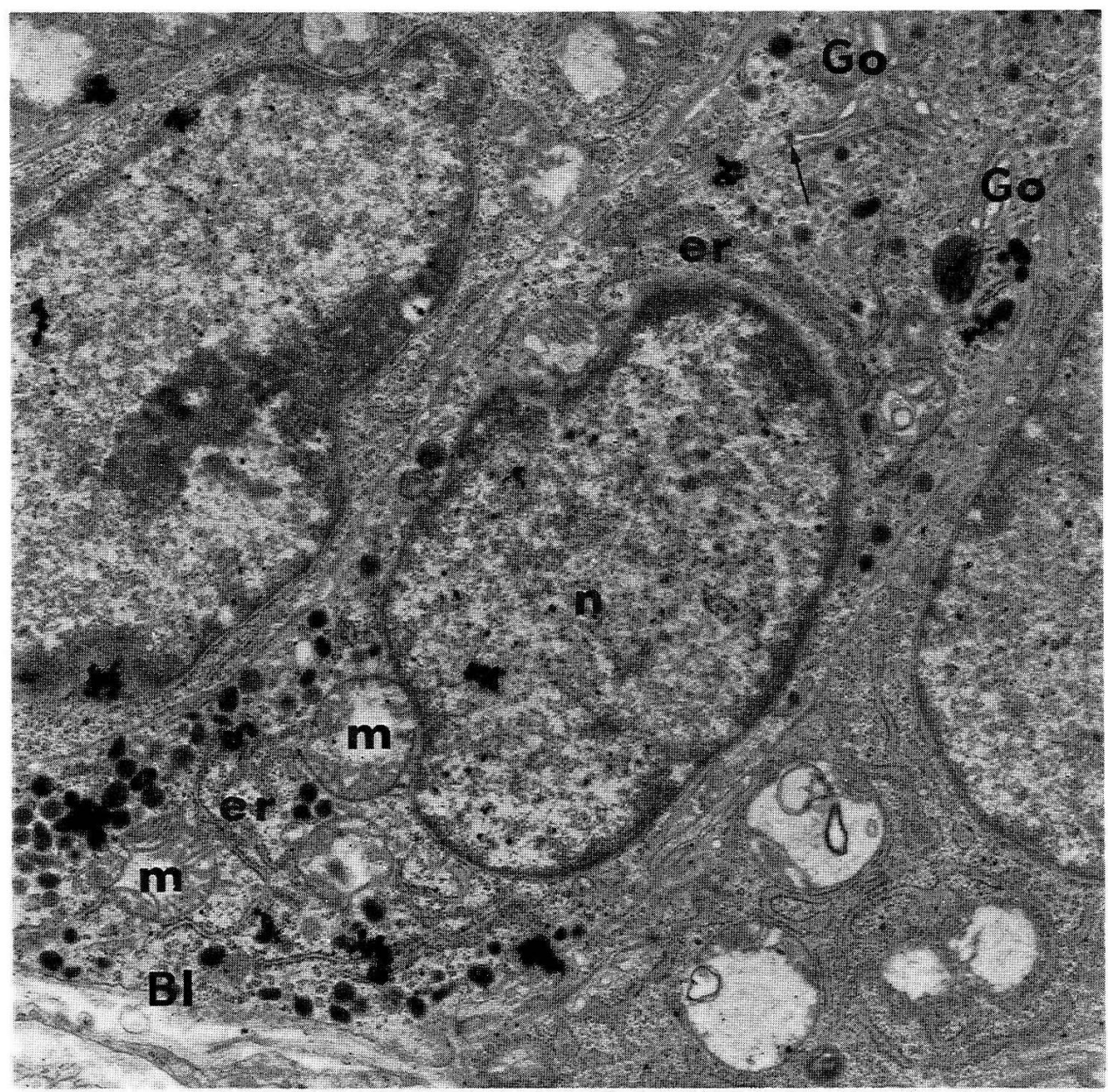

Fig. 6-9. Electron microscope autoradiograms after the injection of L-DOPA- ${ }^{3} \mathrm{H}$. Labels common to all electron microscope autoradiograms: $B l$ basal lamina, $c$ centriole, $e r$ endoplasmic reticulum, Go Golgi complex, $m$ mitochondrion, $n$ nucleus.

Fig. 6. EC cell of the stomach $1 \mathrm{hr}$ after the injection of $\mathrm{L}-\mathrm{DOPA}-{ }^{-} \mathrm{H}$. It is apparent that specific silver grains are mainly associated with the area rich in secretory granules, while the Golgi area is relatively free from them. Note the occurrence of small granules of rounded shape in the Golgi area. The arrow indicates a dense granule in one of the stacked cisterns of Golgi complex. 25 day exposure $\times 14,000$ 
silver grains per unit area was not strikingly larger than that of other epithelial cells especially in the crypt. In the duodenum taken 24 hrs after the injection, no cell type contained a significant amount of specific radioactivity (Fig. 5).

Since the result of light microscope autoradiography showed that very small amounts of radioactivity remained in the specimen fixed 24 hrs after the injection of L-DOPA-3 $\mathrm{H}$, only tissues taken at $1 \mathrm{hr}$ after the injection were processed for electron microscope autoradiography. Typical examples of electron microscope autoradiograms are shown in Figures 6-9. The intracellular distribution of the specific radioactivity was rather similar in all types of the basal-granulated cells. The cytoplasmic area rich in secretory granules had a higher concentration of radioactivity than other

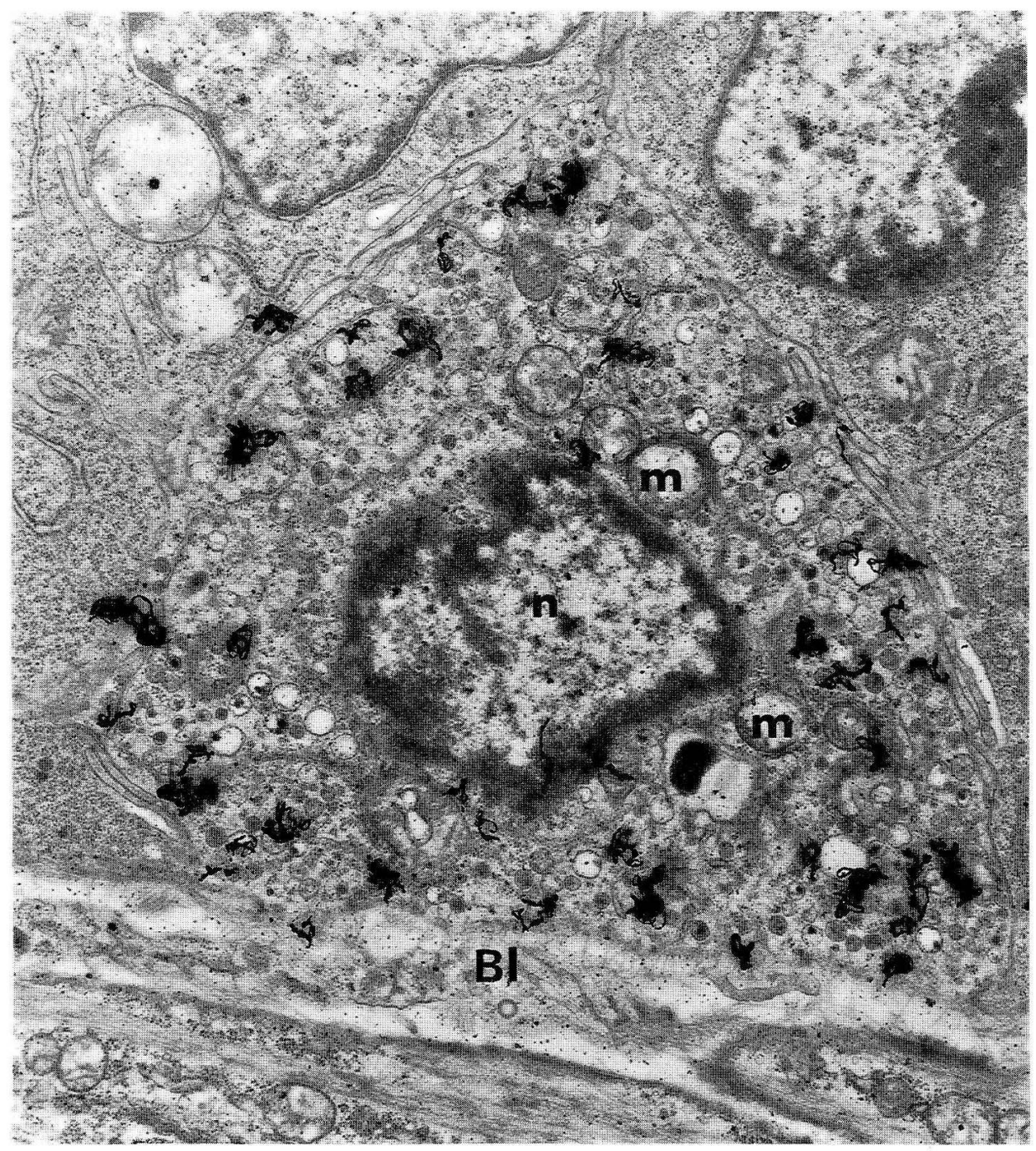

Fig. 7. G cell of the stomach $1 \mathrm{hr}$ after the injection of L-DOPA- ${ }^{3} \mathrm{H}$. Specific silver grains are fairly evenly distributed on the granule-rich cytoplasm. 25 day exposure. $\times 14,000$ 
parts of the cell. Thus, the radioactivity found on the Golgi area was always lower than that in the cytoplasm rich in the secretory granules.

\section{Localization of L-leucine and its metabolites}

At 30 mins after an intraperitoneal injection of L-leucine-3 ${ }^{3} \mathrm{H}$, specific radioactivity was found on all varieties of the epithelial cells of the mucous membrane of both stomach and duodenum (Fig. 10-13). The radioactivity was distinctly higher in epithelial tissue than in the lamina propria. In the stomach, it was substantially lower in the parietal cells than in other types of epithelial cells such as chief cells, surface mucous cells and neck mucous cells. In the duodenum, it was found that the crypt cells such as young enterocytes and goblet cells had larger numbers of specific silver grains than the villus cells including mature enterocytes and goblet cells. Paneth cells in the bottom of the crypt showed the heaviest labeling. It was often almost impossible to identify the type of individual basal-granulated cell in the light microscope autoradiogram stained with toluidine blue, due firstly to the presence of silver grains obstructing the identification of the basal-granules and secondly that the number of silver grains per area of basal-granulated cells was not always greater than that of other epithelial cells.

The pattern of the intracellular distribution of radioactivity studied by electron

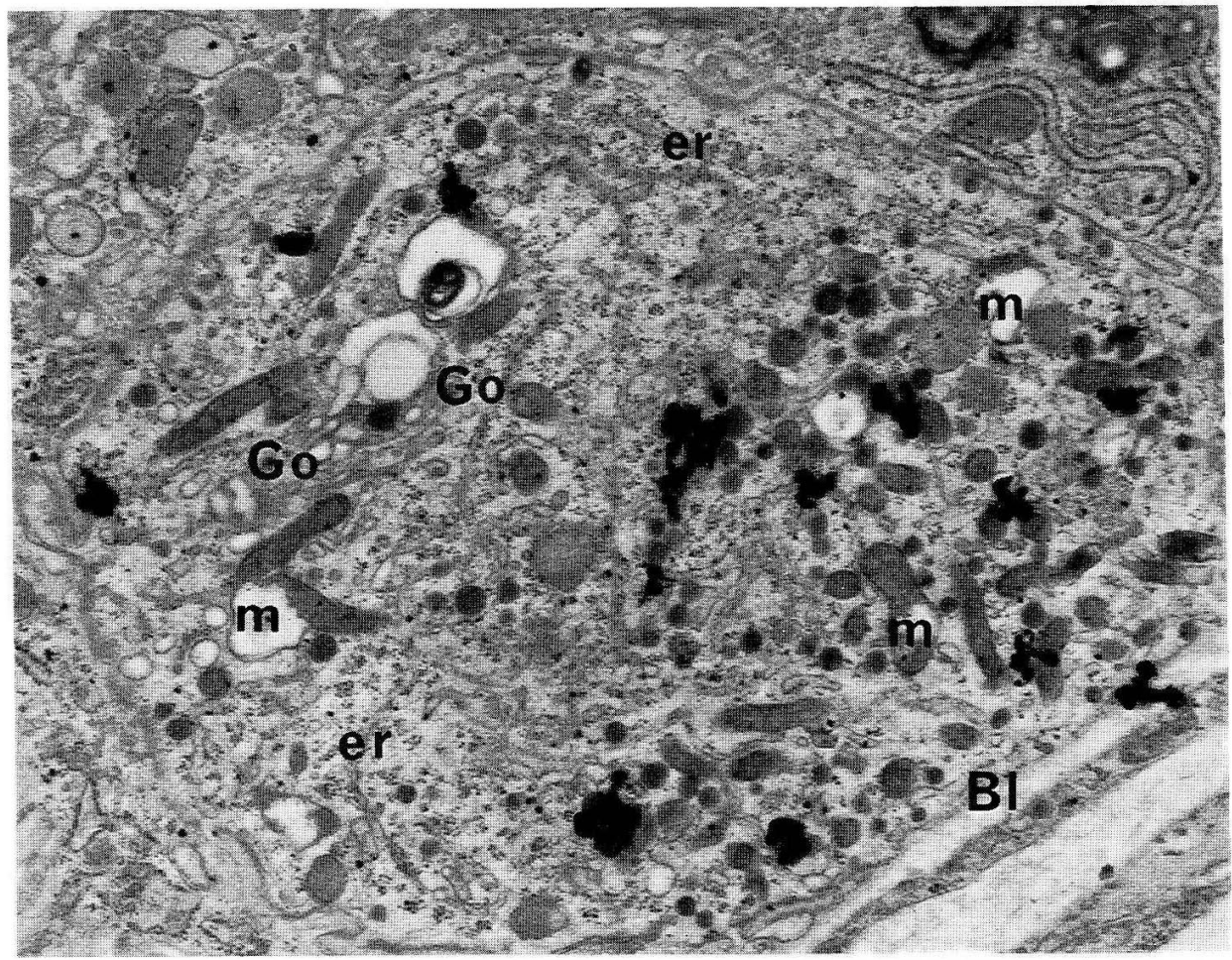

Fig. 8. L cell of the stomach $1 \mathrm{hr}$ after the injection of L-DOPA- ${ }^{3} \mathrm{H}$. The distribution pattern of specific silver grains apparently coincides with that of the secretory granules. 25 day exposure. $\times 16,000$ 
microscope autoradiography was essentially similar in all types of basal-granulated cells. At 30 mins after the injection, the highest radioactivity was found on the Golgi area where, in addition to its lamellar, vesicular and vacuolar elements, several socalled young secretory granules were found. However, by $2.5 \mathrm{hrs}$ after the injection, radioactivity in the Golgi area showed a marked decrease. Specific radioactivity associated with the secretory granules was relatively low in the specimen at $30 \mathrm{mins}$, but by 2.5 hrs after the injection it became significantly higher than that on the Golgi area. Distribution of silver grains was not even in the granule-rich cytoplasm. Especially in the specimen taken 2.5 hrs after the injection they frequently were seen conglomerated as shown in Figure 18. Although it was often difficult to confirm it, the presence of secretory granules containing a great amount of radioactivity at the center of the conglomerated silver grains seemed to be most likely because the occurrence of the grain conglomerations was restricted in the cytoplasmic area dominated by the secretory granules. At both $30 \mathrm{~min}$ and $2.5 \mathrm{hr}$ time points, the nucleus showed a considerable level of radioactivity.

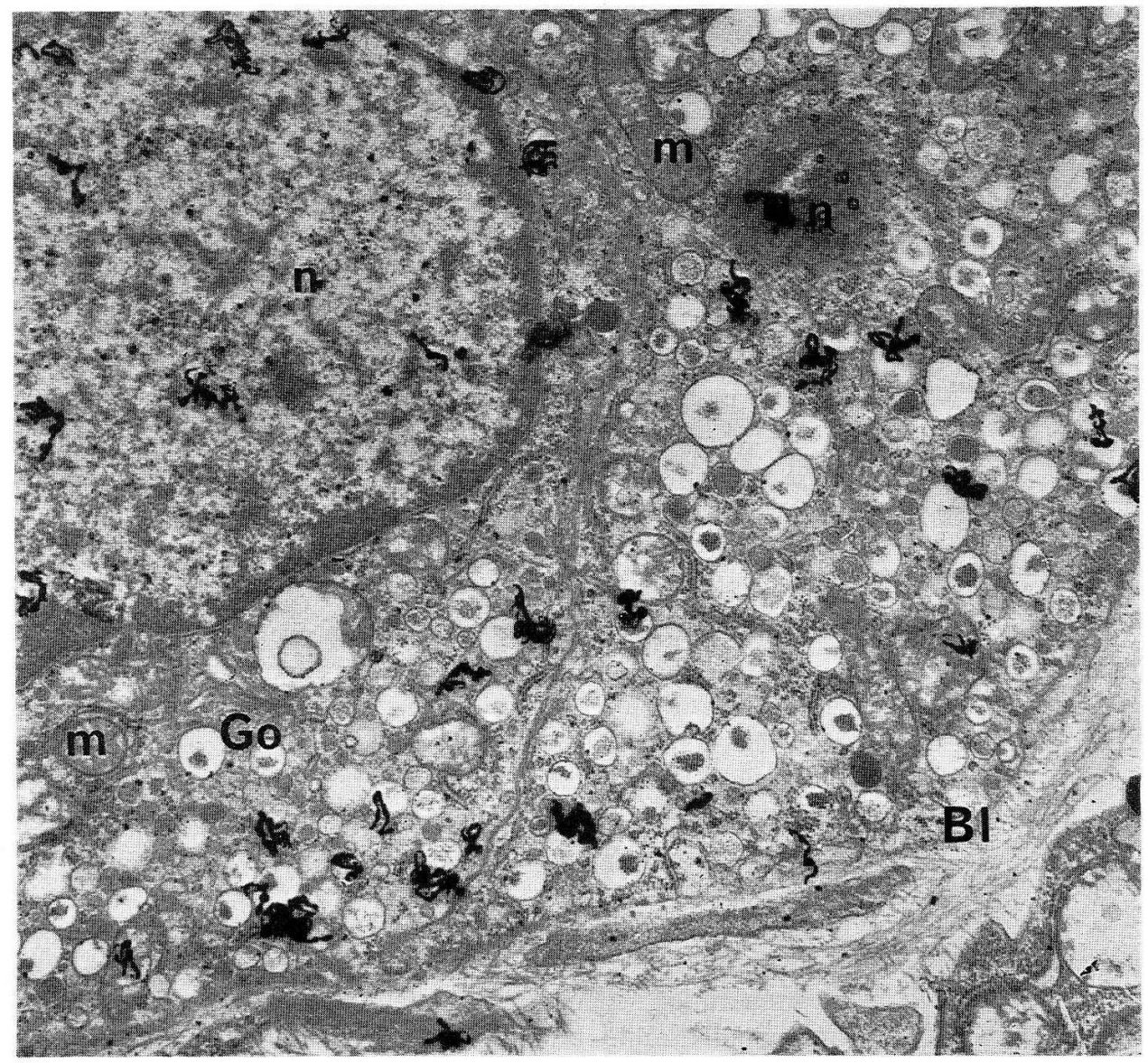

Fig. 9. ECL cells of the stomach $1 \mathrm{hr}$ after the injection of $\mathrm{L}$-DOPA- ${ }^{3} \mathrm{H}$. Specific silver grains are dispersed rather evenly on both the nucleus and cytoplasm of the cells. 25 day exposure. $\quad \times 15,000$ 


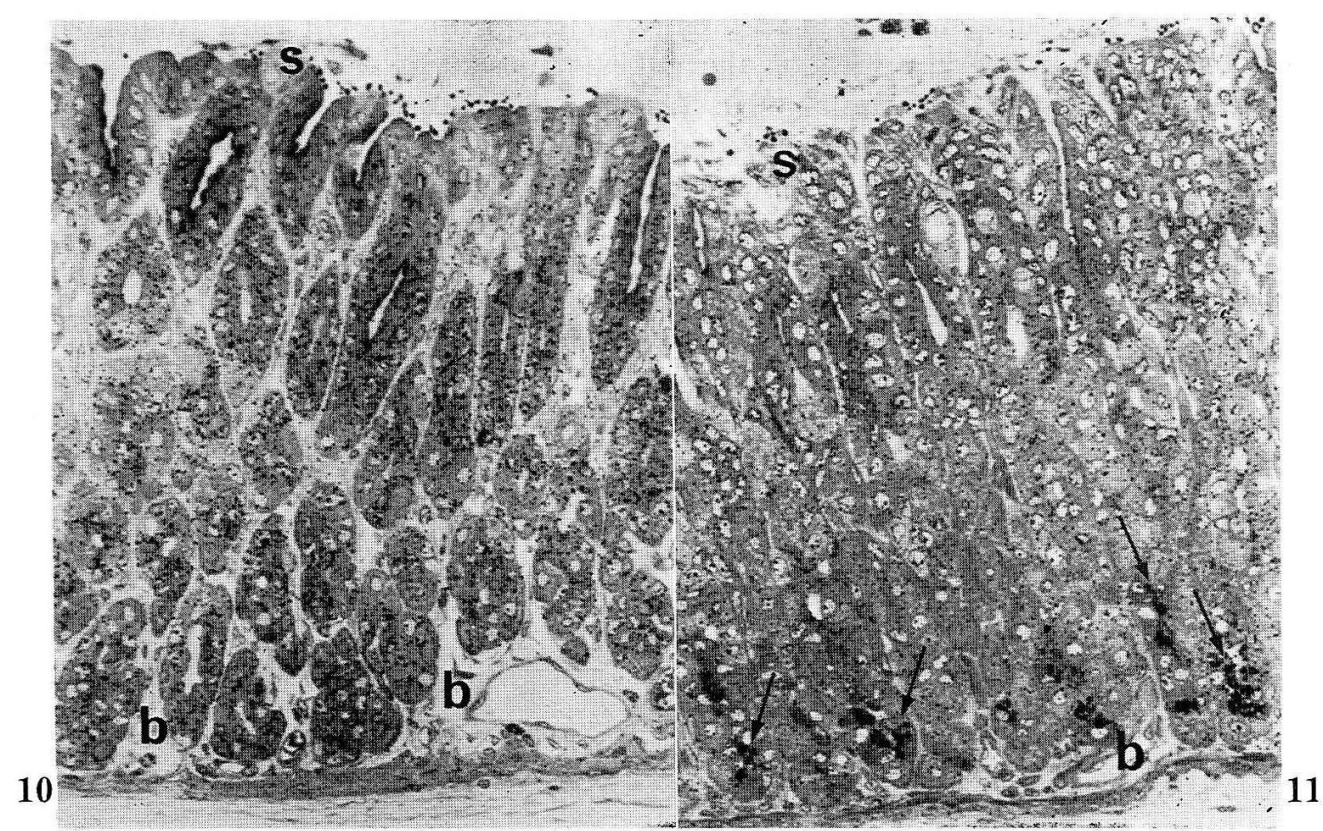

Fig. 10-13. Light microscope autoradiograms of the mouse stomach and duodenum after an intraperitoneal injection of L-leucine- ${ }^{3} \mathrm{H}$.

Fig. 10. Oxyntic cell area of the stomach 30 mins after the injection of $\mathrm{L}$-leucine ${ }^{3} \mathrm{H}$. Specific silver grains are much more densely distributed in the epithelium than in the lamina propria. $s$ Surface epithelium, $b$ bottom of the gastric gland. 7 day exposure. $\times 250$

Fig. 11. Oxyntic cell area of the stomach $2.5 \mathrm{hrs}$ after the injection of L-leucine- ${ }^{3} \mathrm{H}$. Accumulations of silver grains are seen on the apical cytoplasm of the chief cell (arrows). $b$ Bottom of the gastric gland. 7 day exposure. $\times 250$

\section{Discussion}

\section{Fixation of DOPA, leucine and their metabolites}

Glutaraldehyde is known to fix most proteins and polypeptides in situ (see Williams, 1969). It may also fix free L-leucine (Ashley and Peters, 1969). However, as the animals used were perfusion-fixed to wash out the plasma which could contain free $\mathrm{L}$-leucine-3 ${ }^{3} \mathrm{H}$, it seems most unlikely that false localization and excess binding of L-leucine- ${ }^{3} \mathrm{H}$ took place to a significant extent in the material reported in this communication. The specific radioactivity found in various cells after $\mathrm{L}$-leucine- ${ }^{3} \mathrm{H}$ injection was at least mostly due to the presence of newly-formed protein/polypeptide molecules having L-leucine- ${ }^{3} \mathrm{H}$ as a moiety.

Based on their cytological, pharmacological and autoradiographic studies in the adrenal medulla, Coupland and his co-workers (Coupland and Hopwood, 1966; KoBAYASHI and COUPLAND, in preparation) concluded that adrenaline cannot be retained but DOPA, dopamine, and noradrenaline can be retained by means of glutaraldehyde fixation followed by post-fixation with osmium tetroxide. It is most likely that what holds in the adrenal chromaffin cells can also hold in the basal-granulated cells of 


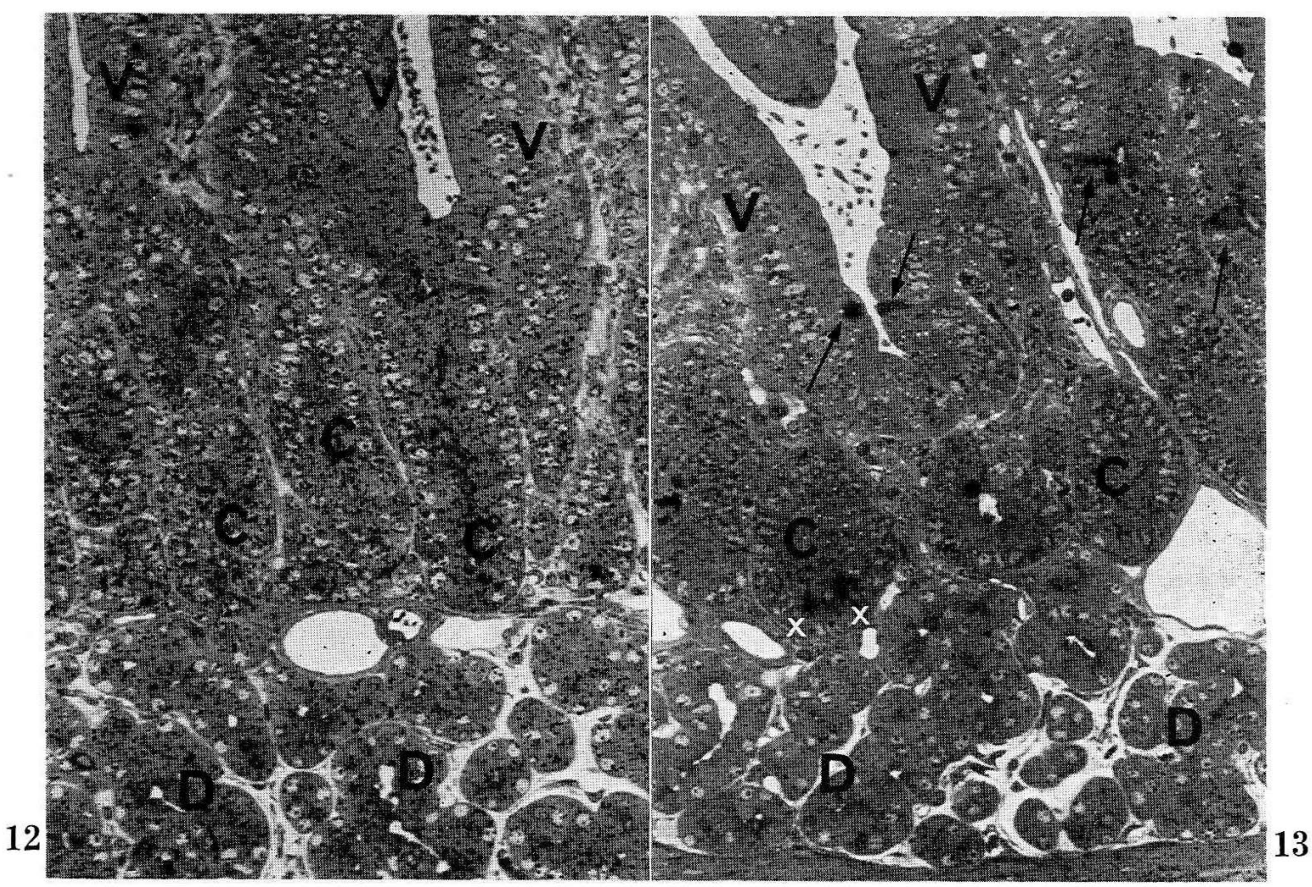

Fig. 12. Duodenal mucosa and duodenal gland $(D) 30$ mins after the injection of $\mathbf{L}$-leucine- ${ }^{3} \mathrm{H}$. It is apparent that the crypt-epithelium $(C)$ is more heavily labeled than the villus-epithelium $(V)$. 7 day exposure. $\times 250$

Fig. 13. Duodenal mucosa 2.5 hrs after the injection of L-leucine- ${ }^{3} \mathrm{H}$. Arrows indicate goblet cells with an accumulation of silver grains. Paneth cells $(x)$ in the bottom of the crypt are also heavily labeled. 7 day exposure. $\times 250$

the gut so far as the fixation of DOPA and its metabolites is concerned. HÅkANSON and OWMAN (1966) reported the occurrence of dopamine- $\beta$-hydroxylase in the basalgranulated cells of the gut in several experimental animals including the mouse; DOPA incorporated in these cells is to be quickly converted to dopamine (HÅkANSON, 1970). Therefore, the radioactivity observed in the present study in the basalgranulated cells of the mouse stomach and duodenum after the injection of L-DOPA${ }^{3} \mathrm{H}$ was probably due to the presence of L-dopamine- ${ }^{3} \mathrm{H}$.

\section{Formation of secretory granules in the basal-granulated cells}

Many protein/polypeptide secreting endocrine cells in the body share a set of ultrastructural and cytochemical characteristics. PEARSE called these cells the APUD series (see the review by PEARse and POLAK, 1974), in which he included ACTH and MSH cells of the pituitary gland, A, B and D cells of the pancreatic islet, chief cell of the carotid body, $\mathrm{C}$ cell of the thyroid gland, $\mathrm{A}$ and $\mathrm{N}$ cells of the adrenal medulla, and all types of basal-granulated cells of the gut. All of these cells contain amines and/or incorporate exogenous amine-precursors and decarboxylate them. APUD cells give metachromasia against toluidine blue and give strong histochemical reaction such as non-specific esterase and/or choline esterase reaction and $\alpha$-glycerophosphate dehydrogenase reaction. The ultrastructure is similar in all types of APUD cells. 


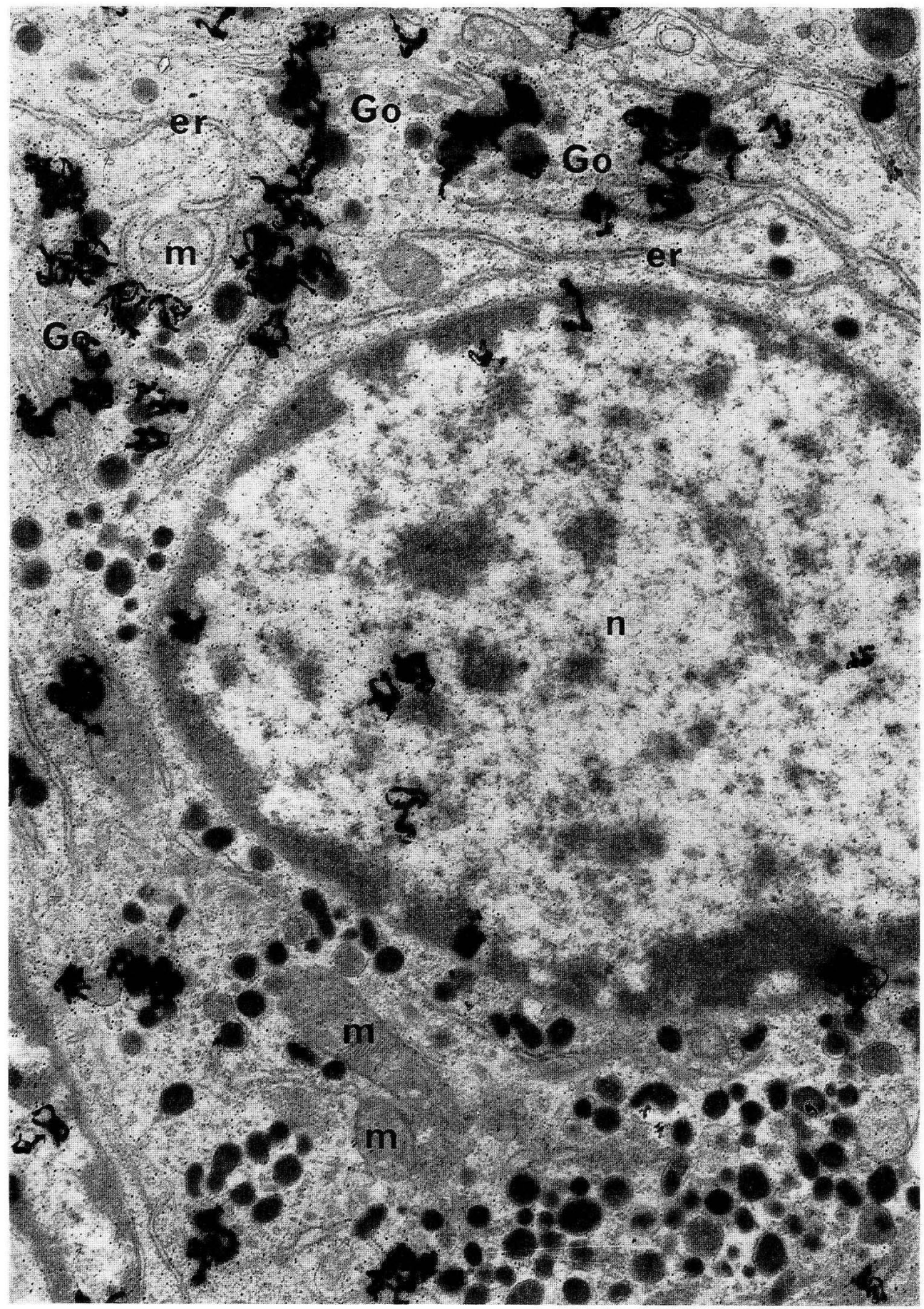

Fig. 14-19. Electron microscopic autoradiograms after an intraperitoneal injection of L-leucine ${ }^{-3} \mathrm{H}$.

Fig. 14. EC cell of the duodenum 30 mins after the injection of L-leucine- ${ }^{3} \mathrm{H}$. Silver grains are apparently much denser in the Golgi area than in the basal cytoplasm rich in secretory granules. 


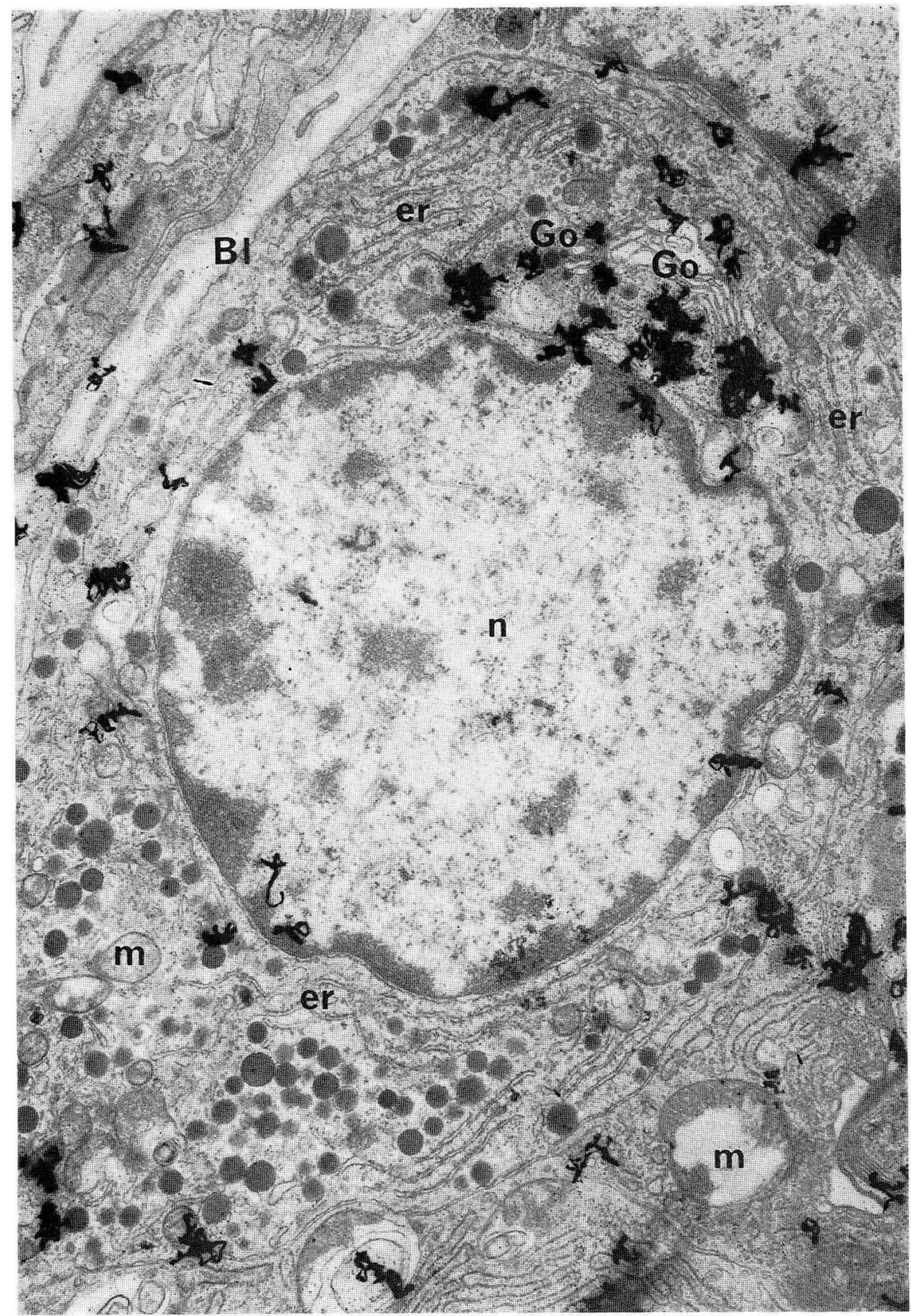

Fig. 15. L (or EG) cell of the stomach 30 mins after the injection of $\mathrm{L}$-leucine- ${ }^{3} \mathrm{H}$. It is apparent that the specific radioactivity is concentrated in the Golgi area. 7 week exposure. $\times 17,000$ 


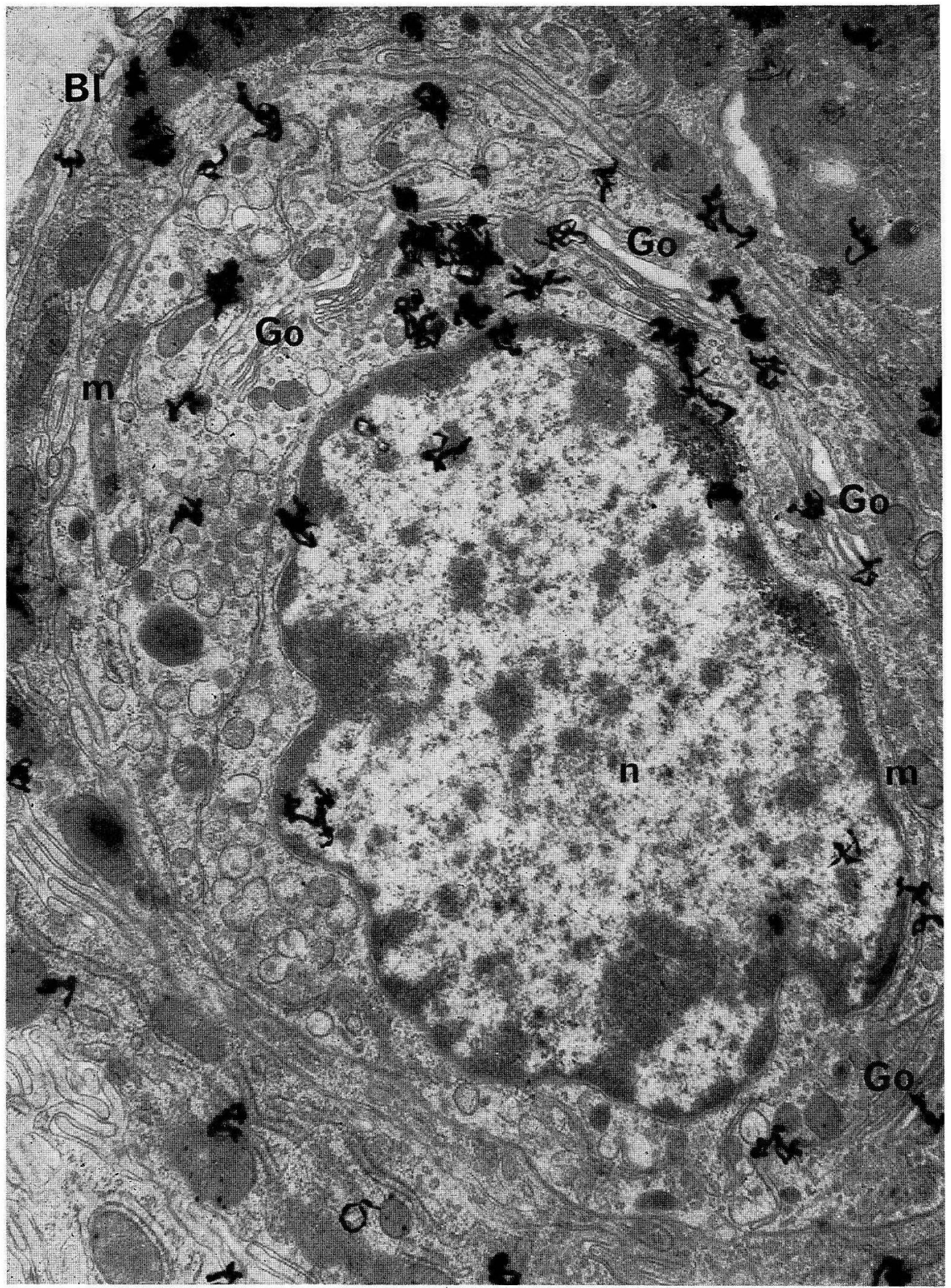

Fig. 16. G cell of the stomach 30 mins after the injection of L-leucine- ${ }^{3} \mathrm{H}$. Specific silver grains are accumulated on the Golgi area. 9 week exposure. $\times 19,000$ 


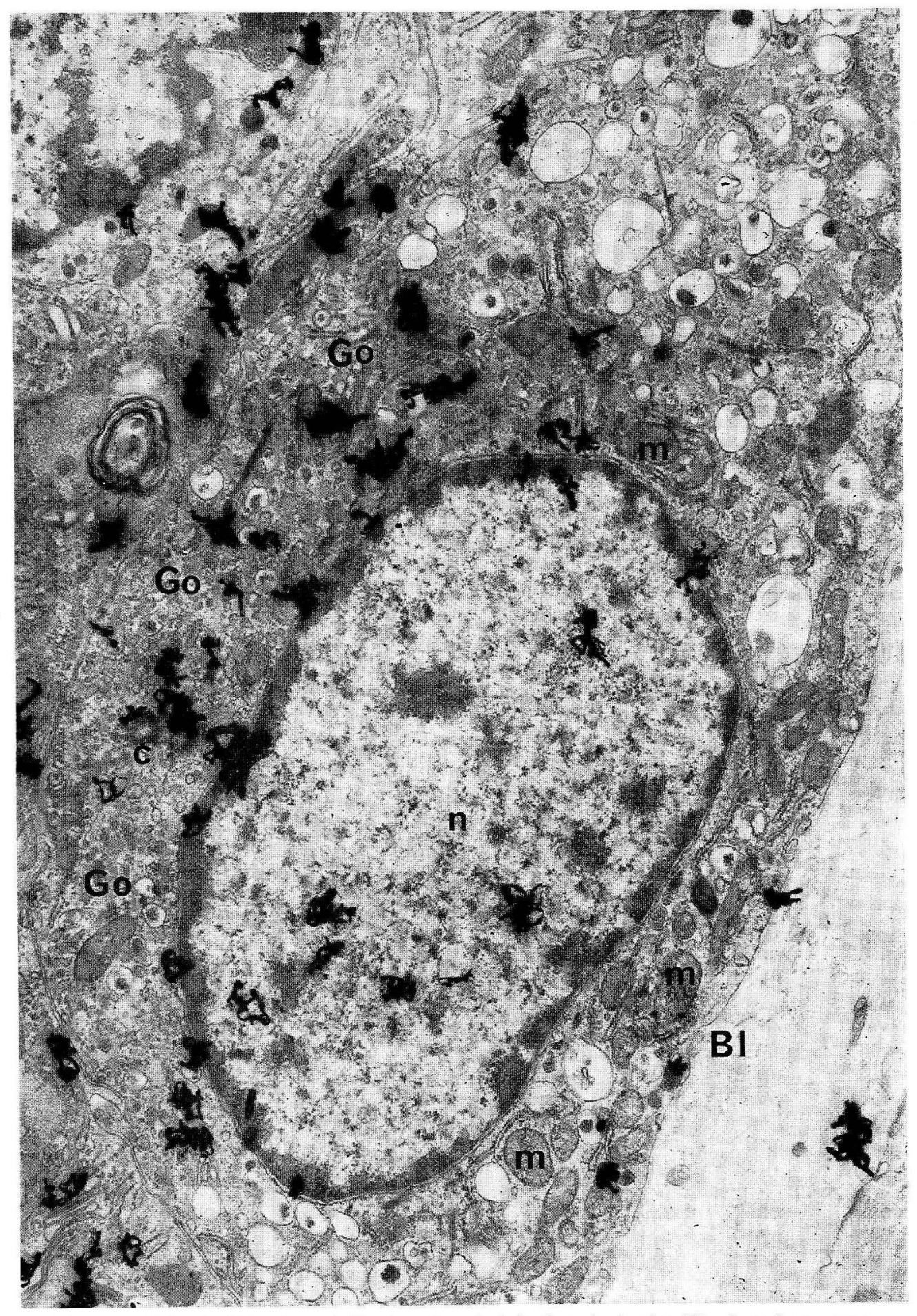

Fig. 17. ECL cell of the stomach 30 mins after the injection of L-leucine- ${ }^{3} \mathrm{H} . \quad 9$ week exposure. 


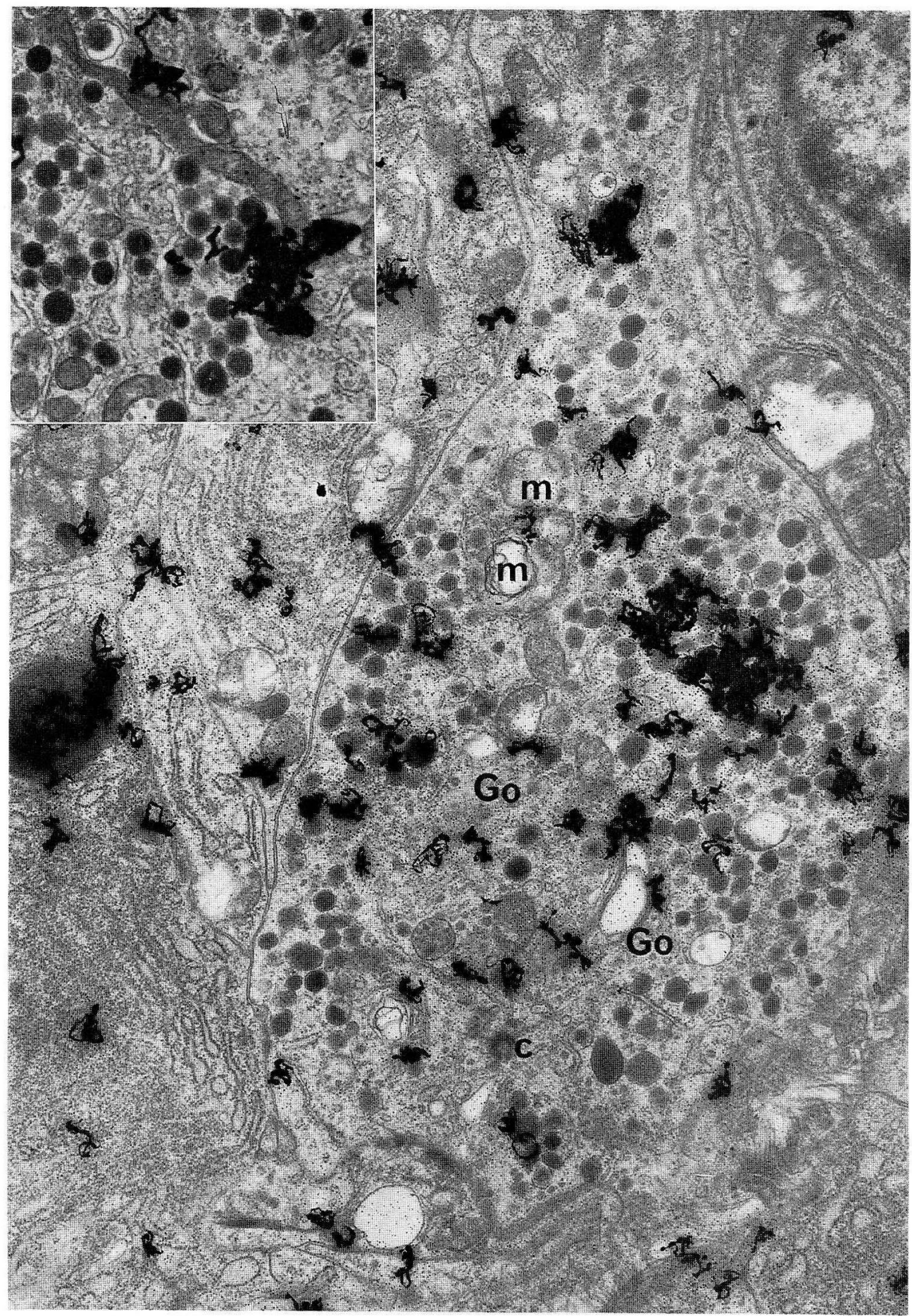

Fig. 18. L (or EG) cell of the stomach $2.5 \mathrm{hrs}$ after the injection of L-leucine- ${ }^{3} \mathrm{H}$. The Golgi area is apparently not so heavily labeled, whereas there are conglomerations of the specific silver grains in the granule-rich cytoplasm. 15 week exposure. $\times 17,000$ Inset: 7 week exposure. $\times 20,000$ 


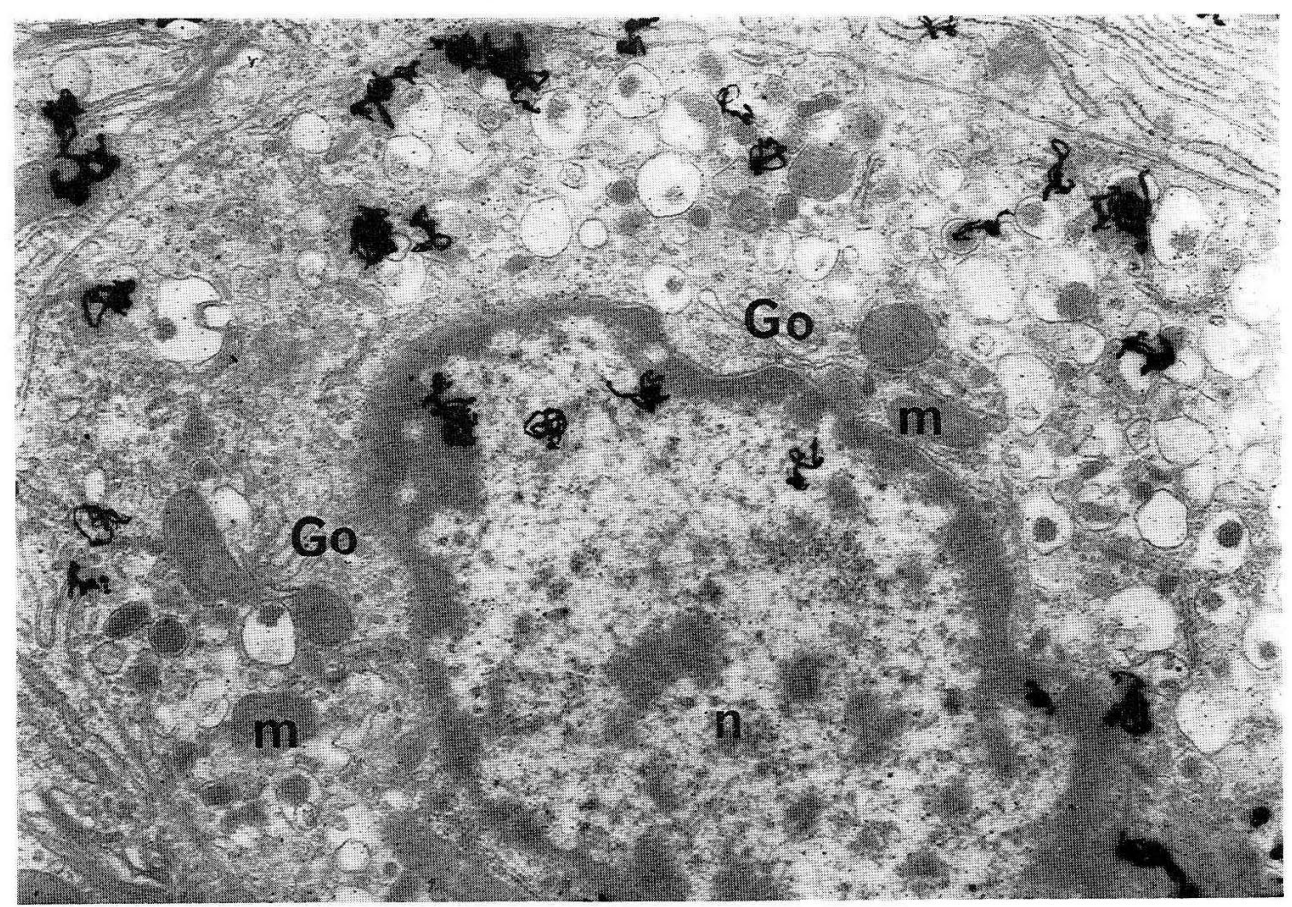

Fig. 19. ECL cell of the stomach 2.5 hrs after the injection of L-leucine- ${ }^{3} \mathrm{H} . \quad 9$ week exposure. $\times 15,000$

Thus, they contain more or less osmiophilic secretory granules with a limiting membrane. The difference in the morphologic appearance of the secretory granules is believed to be due mainly to the difference in the chemical composition of their limiting membrane and/or contents.

Several groups of researchers have studied the uptake and intracellular movement of amine-precursors such as L-DOPA and L-5-hydroxytriptophan in the basalgranulated cells by means of electron microscope autoradiography both in vivo and in vitro (Ito et al., 1969; Forssmann, Perrelet and Tesi, 1970; Forssmann, Wacker and DALDRup, 1971; RuBIN et al., 1971). They showed that all morphologic types of basal-granulated cells studied so far by those authors can incorporate exogenous amine-precursors in significant amounts. However, none of the previous authors reported an accumulation of specific radioactivity on the Golgi complex at any time point after the injection of amine-precursors. The results in the present experiment using L-DOPA-3H have similarly indicated that L-DOPA- ${ }^{3} \mathrm{H}$ incorporated into the basalgranulated cells is located primarily in the area rich in secretory granules. It is very likely that L-DOPA is concentrated in the secretory granules without passing the Golgi area of the cell.

On the other hand, the present experiment using L-leucine- ${ }^{3} \mathrm{H}$ revealed that at 30 min after an intraperitoneal injection the highest radioactivity was found on the Golgi area and at 2.5 hrs it occurred in the secretory granules in all types of basal-granulated cells. This would be explained by the hypothesis that in the basal-granulated cells 
the secretory proteins synthesized in granular endoplasmic reticulum pass through the Golgi area to be matured into secretory granules - a route accepted broadly for the transport of the secretory proteins in exocrine and endocrine glands (see KoBAYASHI and Fujita, 1973). Thus, it is most reasonable to believe that the secretory granules of the basal-granulated cells are formed in the Golgi area, move thereafter to the para-nuclear and basal cytoplasm of the cell and then incorporate amines from the cytosol as they become "mature" secretory granules ready to be released.

\section{Mechanism of hormone-release in the basal-granulated cells}

One of the characteristics of the gastro-enteric hormones is that they are secreted in response to the chemical and/or physical changes in the lumen associated with the food uptake and digestion. Secretion of gastro-enteric hormones starts when the food stuff reaches a certain part of the gut and ends when it is removed from there. Some physiologists supposed there was an intercalation of nerve elements between fooduptake and hormone-release. But, this has been denied by morphologists, because the epithelia of the gut contain no nerve element at all. Fujita and Kовау YSHI (1973) proposed a hypothesis that the basal-granulated cell is a "recepto-secretory" cell which perceives luminal information with the apical process to control its own secretory activity at the cell base. This hypothesis is based on the observation that, at least so far as the human is concerned, the basal-granulated cells of the pyloric antrum and intestine regularly reach the lumen with a characteristic tuft of microvilli (Fujita and Kobayashi, 1973).

The subcellular mechanism of hormone-release from the storage site, i.e., secretory granules in the basal-granulated cells, is still a matter of dispute. ForssmanN and ORCI (1969) proposed that in the G cells the secretory granules release the content by a diacrine mechanism in which the hormone, gastrin, oozes out of the cell traversing the limiting membrane, cytosol and cell membrane. On the other hand, we (Kobayashi, Fujita and Sasagawa 1970; Fujita and Kobayashi, 1971) are of the opinion that the hormone release in all morphologic types of the basal-granulated cells occurs by exocytosis or emiocytosis where the limiting membrane of the secretory granules fuses with the cell membrane and the contents of the granules are released altogether through the pore which is formed at the junction of the two membranes. In a series of experiments stimulating the basal-granulated cells in human as well as animal gut mucosa, we succeeded in obtaining unequivocal electron microscope images indicating the exocy totic release of their granules forming $\Omega$-shaped invaginations at the cell base (Fujita and Kobayashi, 1971; Kobayashi and Fujita, 1973; Osaka, Sasagawa and Fujita, 1974; Fujita, Osaka and Yanatori, 1974). However, the occurrence of $\Omega$-shaped invaginations of the plasma membrane is the only data which supports the exocytosis hypothesis.

The exocytotic granule release in the basal granulated cells could be further supported by considering the other stages of the secretory activity of the cell, since it is certain that the process of granule release is intimately related to the formation and maturation of the secretory granules and to the fate of the limiting membrane of the granules after releasing the contents. Thus, the diacrine hypothesis alludes as a necessary consequence that empty granules or skeletons of the secretory granules are refilled with newly-formed proteins, amines, etc. to be repeatedly used as the 
storage site of these substances. On the other hand, if the granule release takes place by exocytosis, the secretory granules cannot keep their form once they have released their contents so that refilling of empty granules is impossible. The results reported in the present communication strongly suggest that the secretory granules and their protein contents are formed in or via the Golgi area, and this indicates that newly-synthesized proteins do not enter the "empty granules" or "used skeletons of the secretory granules" which have never been found in or near the Golgi area. These observations on the granule formation in the basal-granulated cells favor our view that the release of gastro-enteric hormones takes place by exocytosis rather than diacrine mechanism.

\title{
マウスの胃腸内分泌細胞における L-DOPA と L-ロイシンおよびそれらの 代謝産物の取込みと細胞内の局在に関する電顕オートラジオグラフィー による研究
}

\author{
小林繁
}

2 匹のマウスの腹腔内に 体重グラムあたり $50 \mu \mathrm{Ci}$ の L-DOPA-3H を注射し, 1 時間後, 24時間後に動物を殺して 胃および十二指腸粘膜の小片をグルタールアルデヒドとオス ミウム酸によるいわゆる二重固定し，光顕および電顕オートラジオグラフィーの手法で， 胃腸内分泌細胞に打ける L-DOPA とその代謝産物の存在を示す放射能の分布をしらべた. 注射後 1 時間では, 胃腸粘膜の基底果粒細胞のうちで $\mathrm{G}, \mathrm{L}(\mathrm{EG}), \mathrm{ECL}$ 細胞等に比べて, $\mathrm{EC}$ 細胞により多量の放射能が見出された. 注射後 24 時間のものでは, 一部の $\mathrm{EC}$ 細胞に のみ放射能が残っていた．電顕オートラジオグラフィーでは， L-DOPA-3H に由来する 放射能は主に胃腸内分泌細胞の分泌果粒に富む細胞質にあり，ゴルジ野にはほとえど 見出されなかった。

一方, 胃腸内分泌細胞における分泌蛋白質の合成経路を研究する目的で, 2 匹のマウ スの腹腔内に 体重グラムあたり $100 \mu \mathrm{Ci}$ の Lーロイシシー3H を注射し，30分後と 2 時間半 後の放射能の局在をしらべた。この結果すべての型の胃腸内分泌細胞が L-ロイシンを取 込久蛋白質を合成していることが明らかとなった，注射後30分では, 放射能は主にゴル ジ野にあったが，注射後 2 時間半では 放射能の分布と分泌果粒のそれとが ほぼ一致し ており,また多量の放射能を含有する分泌果粒の存在を示すと思われる銀粒子のかたま りが見られた。

以上の結果は胃腸内分泌細胞においても, ゴルジ野にて形成される分泌果粒はここ ですでに蛋白質を含えでおり，その後 細胞質基質よりアミン等を取込えで成熟し，開口 型放出它行うことを示唆する. 


\section{References}

Ashley, C. A. and T. Peters: Electron microscopic radioautographic detection of sites of protein synthesis and migration in liver. J. Cell Biol. 43: 237-249 (1969).

Capella, C., E. Solcia and G. Vassallo: Identification of six types of endocrine cells in the gastrointestinal mucosa of the rabbit. Arch. histol. jap. 30: 479-495 (1969).

Coupland, R. E. and D. Hopwood: The mechanism of the differential staining reaction for adrenaline- and noradrenaline-storing granules in tissues fixed in glutaraldehyde. J. Anat. 100: $227-243$ (1966).

Forssmann, W. G. and L. Orci: Ultrastructure and secretory cycle of the gastrin-producing cell. Z. Zellforsch. 101: 419-432 (1969).

Forssmann, W. G., L. Orci, R. Pictet, A. E. Renold and C. Rouiller: The endocrine cells in the epithelium of the gastrointestinal mucosa of the rat. An electron microscope study. J. Cell Biol. 40: 692-715 (1969).

Forssmann, W. G., A. Perrelet und D. Tesi: Untersuchungen zur funktionellen Morphologie der endokrinen Zellen im Magen-Darm-Trakt. Verh. Anat. Ges. 64: 141-148 (1970).

Forssmann, W. G., P. Wacker und J. Daldrup: Ultrastrukturelle Autoradiographie zum Stoffwechsel der biogenen Amine im Magen-Darm-Trakt und in anderen Organen. Verh. Anat. Ges. 65: 19-29 (1971).

Fujita, T. and S. Kobayashi: Experimentally induced granule release in the endocrine cells of dog pyloric antrum. Z. Zellforsch. 116: 52-60 (1971).

- The cells and hormones of the GEP endocrine system. The current of studies. In: (ed. by) T. Fujita: Gastro-entero-pancreatic endocrine system. A cell-biological approach. Tokyo, Igaku Shoin, 1973. (p. 1-16).

Fujita, T., M. Osaka and Y. Yanatori: Granule release of enterochromaffin (EC) cells by cholera enterotoxin in the rabbit. Arch. histol. jap. 36: 367-378 (1974).

Håkanson, R.: New aspects of the formation and function of histamine, 5-hydroxy-tryptamine and dopamine in gastric mucosa. Acta physiol. scand. Suppl. 340: 1-134 (1970).

Håkanson, R. and Ch. Owman: Distribution and properties of amino-acid decarboxylase in gastric mucosa. Biochem. Pharmacol. 15: 489-499 (1966).

Ito, S., R. E. Coggeshall, J. S. Mueller and B. Yaksta: Radioautography of enterochromaffin cells. J. Cell Biol. 43: 57a (1969).

Kobayashi, S. and T. Fujita: Emiocytotic granule release in the basal-granulated cells of the dog induced by intraluminal application of adequate stimuli. In: (ed. by) T. Fujita: Gastro-enteropancreatic endocrine system. A cell-biological approach. Tokyo, Igaku Shoin, 1973. (p. 49-58).

Kobayashi, S., T. Fujita and T. Sasagawa: The endocrine cells of human duodenal mucosa. An electron microscope study. Arch. histol. jap. 31: 477-494 (1970).

Osaka, M., T. Sasagawa and T. Fujita: Granule release from endocrine cells in acidified human duodenal bulb: An electron microscope study of biopsy materials. Arch. histol. jap. 37: 73-94 (1974).

Pearse, A. G. E.: The endocrine cells of the GI tract: Origins, morphology and functional relationships in health and disease. Clinics in Gastroenterol. 3: 491-510 (1974).

Pearse, A. G. E., I. Coulling, B. Weavers and S. Friesen: The endocrine polypeptide cells of the human stomach, duodenum and jejunum. Gut 11: 649-658 (1970).

Pearse, A. G. E. and J. M. Polak: Endocrine tumours of neural crest origin: neurolephomas, apudomas and APUD concept. Med. Biol. 52: 3-18 (1974).

Polak, J. M.: Endocrine cells of the gut. In: (ed. by) C. Wastell: Chronic duodenal ulcer. London, Butterworths, 1974. (p. 27-52).

Rubin, W., M. D. Gershon and L. L. Ross: Electron microscope radioautographic identification of serotonin-synthesizing cells in the mouse gastric mucosa. J. Cell Biol. 50: 399-415 (1971).

Salpeter, M. M. and F. A. McHenry: Electron microscope autoradiography. In: (ed. by) J. K. Koehler: Biological electron microscopy. Berlin, Springer Verlag, 1973 (p. 113-152). 
Sasagawa, T., S. Kobayashi and T. Fujita: Electron microscope studies on the endocrine cells of the human gut and pancreas. In: (ed. by) T. Fujita: Gastro-entero-pancreatic endocrine system. A cell-biological approach. Tokyo, Igaku Shoin Ltd. 1973. (p. 17-38).

Williams, M. A.: The assessment of electron microscopic autoradiographs. Advan. opt. Electron Microsc. 3: 219-272 (1969).

小林 繁

厂951 新潟市旭町 1

新潟大学医学部

第三解剖学教室
Dr. Shigeru KoBayashi

Department of Anatomy

Niigata University School of Medicine

Niigata, 951 Japan 